\title{
Ideological State Apparatuses in Dystopian Novels
}

\author{
By Kory Wise
}

\section{$\cos$}

\section{ABSTRACT}

Dystopian novels have been topping best-seller lists for nearly a hundred years, but not many people have examined why this is the case or what makes them so effective at warning readers about what we could become in a not too distant future. Perhaps it is these texts' connection to the real world that plays into our fascination with the genre. This paper establishes this connection by examining the worlds of three popular dystopian novels and the ways in which they support Louis Althusser's theory of Ideological State Apparatuses. This study will ideally enable readers to recognize the tools and real-life strategies that structure dystopian fictional worlds. 
For roughly a century, dystopian novels have been a popular genre of literature among people of all ages. There is something about them that captures our imagination, makes us fear the worlds they construct, and forces us to ask probing questions about our own lives and societies. Their ongoing popularity begs readers to ask whether there is a common element to these novels that keeps people coming back for more. What are the overarching themes or ideas that make them effective at warning humanity of what it could become? What are some of the tools they use to do this? One answer to these questions lies in Louis Althusser's theory of ideological state apparatuses and the ways in which dystopian novels throughout the last century illustrate his ideas. This study will examine Fahrenheit 451 by Ray Bradbury (1953), The Handmaid's Tale by Margaret Atwood (1985), and The Circle by Dave Eggers (2013).

In "Ideology and Ideological State Apparatuses," Althusser examines the ways in which a state asserts power over its subjects and controls them for the purpose of reproducing labor power. He sees this happening in two ways. The first is directly through Repressive State Apparatuses, or "RSAs," a "hard power" which belong entirely to the public domain (Althusser). These are controlled directly by the state and act as agents enforcing the state's will in an obvious manner, predominantly by repression (Althusser). This includes such things as the police, army, prison system, judiciaryanything that is state-controlled. Althusser believes this apparatus operates primarily through both mental and physical coercion and violence.

The Ideological State Apparatuses, or "ISAs," meanwhile, are part of the private domain and are controlled or influenced by the subjects within the apparatus (Althusser). This "soft power" includes things like churches, schools, families, culture (literature, fashion, sports, technology, etc.), and tools of communication (press, radio, television, etc.) that create an ideology, or "a system of the ideas and representations (images, myths, ideas or concepts, according to the case) which dominate the mind of a man or a social group" (Althusser; Lin). The goal of the ISA is to brainwash people into accepting the state's ideology not through violence but through the desire to avoid scorn and humiliation. Authors of dystopian literature fear ISAs the most because they enable the state to maintain its power, force a loss of identity among individuals, and strip subjects of the knowledge and ability they would need to easily go against the state. 
It is important to note that these apparatuses do not need to be born of malicious intentions or some "evil empire" seeking to take control of a people for its own benefit. On the contrary, they are often the result of good intentions that yield negative results. After all, the etymological definition of "dystopia" is "bad utopia"-a utopia that has failed or gone horribly wrong ("Dystopia"). This is certainly true of the dystopian societies found in The Circle, The Handmaid's Tale, and Fahrenheit 451 , worlds in which people have given up their freedoms and liberties for the sake of the greater good or are in the process of doing so. Whether born of good intentions or not, though, the ISAs Althusser wrote about are on full display in these dystopian novels, all of which show, in a grotesque way, how ISAs can be used to oppress the individual.

Perhaps the most important Ideological State Apparatus to Althusser is the educational ISA, or the system of different public and private "schools" through which "students" learn the rules of good behavior, develop their civic conscience, and learn to respect the rules of order that enforce their inferiority (Althusser). Atwood uses this idea to form the foundation of her fictional society, Gilead, in The Handmaid's Tale. In the book, the women of Gilead are forced to enroll at the Rachel and Leah Re-education Centers to learn lessons of sexual morality, the importance (or mission) of childbearing, and obedience to God (Atwood 88). The Handmaids are inferior to their teachers, the "Aunts," whose job is to train the maids and transfer the ideology of the state unconsciously. The Aunts justify the young women's situation by telling them to "think of it as being in the army" (Atwood 7). They are also told that, as time passes by, their situation will become more ordinary and they will grow used to it (Moradi and Azizmohammadi 80).

Re-education does not take place solely at the Rachel and Leah Centers, though. It also occurs all throughout the women's lives as Handmaids. Anytime they go against the law or show disobedience toward the Marthas, their superiors, or their Commanders' wives, they are reprimanded and punished (Atwood 16). The women are also prevented from being able to educate themselves. Tools for self-education, like books, are restricted in Gilead. Typically, they are kept out of sight and locked away in boxes (Atwood 137). The reason for this is that books hold promise within their pages. As Offred says,

They dealt in transformations; they suggested an endless series of possibilities...They suggested 
one adventure after another, one wardrobe after another, one improvement after another, one one man after another. They suggested rejuvenation, pain overcome and transcended, endless love. The real promise in them was immortality. (Atwood 157)

Books would offer too much hope to the Handmaids who read them, giving them the idea that perhaps, if they all stood as one, they would have enough power to overthrow their oppressive society. Gilead could not afford for this to happen, so these educational tools were restricted.

Ray Bradbury uses the educational ISA in a similar way in his novel Fahrenheit 451. In his futuristic American society, books are banned and "firemen" hunt down and destroy any book that remains in the country. People can be arrested or killed for reading or owning books of any kind, because, much like in Gilead, books can lead people to ponder issues such as freedom and happiness. Having non-questioning, non-reading citizens on its hands allows the government to enforce its own will much more easily. One way in which it does this is evident when the young Clarisse tells protagonist Guy Montag about a typical school day. Important social and educational activities like talking or asking questions are not encouraged (Bradbury 27). Instead, students are subjected to "an hour of TV class, an hour of basketball or baseball or running, another hour of transcription history or painting pictures, and more sports" (Bradbury 27). When they are in class, there is no teacher-student interaction, because students are fed information by a film-teacher for hours at a time (Bradbury 27). Captain Beatty of the fire department also provides detail about how the school system has been changed in this futuristic society: "School is shortened, discipline relaxed, philosophies, histories, languages dropped, English and spelling gradually neglected, finally almost completely ignored" (Bradbury 53). In her article, "Subject and State: Ideology, State Apparatuses and Interpellation in Fahrenheit 451," Evrim Koç says that, without classes like science, mathematics, ethics, etc., students are not taught to think or question as they should, which is exactly what the ruling ideology desires (117). Instead, intellectuals become the outsiders, ignorant individuals become the norm, liberal arts colleges shut down, and the educational ISA maintains an easily controlled society that is unfriendly to reading, thinking, and questioning.

In The Circle, Dave Eggers shows how the educational Ideological State Apparatus can be used to produce a society that celebrates education and knowledge but still has a similar effect on its people 
as the world of Fahrenheit 451. One of the eponymous technology company's mottos is "All that happens must be known," and knowledge is celebrated as a fundamental human right (Eggers 68, 303). In fact, to withhold knowledge from somebody, to deprive them of something to which they have a right, is viewed as stealing from them (Eggers 303). As a result, the Circle works to create a collective record of everything that happens in the world, giving people the tools they need to know everything. It begins with SeeChange cameras being placed around the world to "know the previously unknown" and allow people to tune in to live video streams from any location in the world (Eggers 63). Not long after, people are willing to "go transparent" and wear a camera around their neck to broadcast every event of their day to day lives (Eggers 210).

The result of this ideology on the Circle's customers is similar to that of the educational ISA in The Handmaid's Tale and Fahrenheit 451. While the company's actions are veiled as promotion of individuals' rights and education, they only serve to promote the knowledge of the collective or the company as a whole. No individual can truly access all the information available to them at once, and as the novel demonstrates, when they do, it has adverse effects on them. The main character Mae's exboyfriend Mercer is driven to commit suicide after he can no longer handle the harassment of people across the world, and her close friend Annie, an executive at the Circle, has a mental breakdown when information concerning her family's history is made public (Eggers 466,495$)$. The rapid pace at which these feeds are updated, as well as the large amount of information for people to consume, creates a knowledge overload that individuals are not able to sift through. They are unable to be free-thinking individuals that stop and consider the information being presented to them. Much like in Fahrenheit 451, they consume whatever they can without giving it much thought, making them easy to control. As a result, only the RSA, in this case the Circle, is able to benefit from the educational ideology that they have forced upon the society.

According to Althusser, another Ideological State Apparatus that is vital to a state's survival is the communications ISA, because it crams messages of "nationalism, chauvinism, liberalism, moralism, etc." into people's lives every day (Althusser). This ISA involves a manipulation of the tools of communication that are widely available to the public, such as television, technology, or even talking face to face. In Fahrenheit 451, the dominant tool of communication is the television. Large 
Large TVs cover all four walls of people's living rooms, and even when people are not watching them, they have their "ears plugged with electronic bees that...[hum] the hour away" (Bradbury 16). Citizens are tuned in to the entertainment industry at all times, especially in their private spaces, and this provides the ideal opportunity for it to reinforce the state's ideology as if they were in the public space. According to Joseph Hurtgen, from his article, "Archival Domination in Fahrenheit 451," because all their time is consumed by this media, people have no time or ability to actually communicate with one another, and they just become reflections of what they see and hear on the screens (38). This is most evident in Montag's wife, Mildred, who comes to reflect the pacing of television shows in her bodily movements:

The door to the parlor opened and Mildred stood there looking in at them, looking at Beatty and then at Montag. Behind her the walls of the room were flooded with green and yellow and orange fireworks sizzling and bursting to some music composed almost completely of trap drums, tom-toms, and cymbals. Her mouth moved and she was saying something but the sound covered it ... The fireworks died in the parlor behind Mildred. She had stopped talking at the same time. (Bradbury 56-7)

Not only has the television stopped Mildred from being able to effectively communicate, Hurtgen argues, but it has also "colonized" her speech, as seen in the fact that she stops speaking when the sounds from the television cease (41). This also symbolizes her closer relationship to the television than her own husband (41). Because of people's close bonds to their televisions, the only conversations that take place in these households are between the state and the private citizen, not between living, breathing people (44).

The state is then able to deliberately manipulate this television-centered society by broadcasting things that suit its political agenda. For example, when Montag is being chased by a mechanical hound near the end of the novel, it is broadcast on every TV screen across the country, turning it into a show that encourages people to tune in and do their part in stopping this "criminal" (Bradbury 141). When Montag manages to escape, the broadcasters show the hound catching a different individual who they claim is Montag, but they do not show the individual's face clearly (Bradbury 143). People are just expected to believe that the government did its job and caught the 
traitor who went against the societal norm. Hurtgen says that this type of broadcast, while providing entertainment to its viewers, also ensures that the public is aware of the state's power, producing obedience and conformity in those who watch (39). In this case, the state uses the communications ISA to secure its authority, keep its citizens in line, and form their mindsets according to its own will.

The Circle utilizes the communications ISA in a similar way. Much like with Bradbury, the apparatus in Eggers's novel seemingly celebrates communication by doing everything it can to foster communication between people and provide the tools needed to make it easier, but the end result is actually much different. The Circle encourages relationships among people and participation in events and activities by assigning each of its employees a "PartiRank" (participation rank) that reflects their level of engagement with the company and the people who work there (Eggers 101). When people do not respond to one another's invitations or messages, their PartiRank goes down, and this reflects the way they are perceived at the company. This creates a society in which everyone believes that everyone else needs to be responded to, taken seriously, and given time and attention.

This emphasis on everybody's voice mattering eventually creates a world in which no one can really be heard, thereby effectively silencing communication. As Mercer tells Mae, "the tools you guys create actually manufacture unnaturally extreme social needs" that eliminate one's ability to effectively communicate (Eggers 134). It is impossible for anyone to respond to the thousands of "zings," texts, and phone calls they receive in one day, but when they do not, friendships end and people are offended, as was the case when Mae was unable to answer attempts to communicate with her in a "timely" manner of a few minutes (Eggers 114). It also allows the state to drown out the voices of dissenters, or at least ignore them until tragedy occurs, as it does when Mercer commits suicide (Eggers 466). In place of critical thought and opinions, the Circle reinforces its company mantra hundreds of times a second, and because people are unable to process all of the messages they are taking in, the products that constitute the communications ISA really only benefit the Circle itself.

Because both Fahrenheit 451 and The Circle warn about the use of technology to oppress people, as do other dystopian novels such as Brave New World by Aldous Huxley, 1984 by George Orwell, and We by Yevgeny Zamyatin, it is necessary to draw an explicit connection between the two novels and consider why this is the case. To start, one must reflect on the idea of a dystopia as a "bad 
utopia." Utopian visions imagine the perfect human society as something that exists in the future, hopefully to be achieved after we make even more technological advancements that will help us achieve harmony. This is true even of Thomas More's Utopia, the first of such books to be written. Dystopian novels tell stories in which this does not end up being the case. If a utopia were to fail, it is logical that technology would be one of the direct causes, especially since it is still new to us in scope of human history. We cannot predict where it will take us next or assume that we totally understand its role in our lives. It is understandable, then, that dystopian authors would have so many anxieties about the role of technology. Bradbury was certainly fearful of the role that he saw television playing in the future, as well as the prominence people gave it in their lives, and Eggers is apprehensive of twenty-first century technology like the internet, mobile phones, and social media. While there is great potential for technology to improve the lives of mankind, as we have seen in our own present age, there is an equal potential that it can be taken too far and used for control, surveillance, and oppression, as seen in Fahrenheit 451 and The Circle.

Finally, Althusser writes about the religious ISA and the ways in which it can be a powerful tool for the state's advantage. This frequently involves the perversion, manipulation, or all-out destruction of a particular religion, or all religious faith, in a society. This is most evident in The Handmaid's Tale, in which the state participates in the cherry-picking of Christian scriptures to suit its needs and agenda. Specific verses that extol the value of marriage, emphasize meekness and humility, and absolve men of adultery, as long as its purpose was for childbirth, while condemning women for the same crime are used to construct the laws of Gilead. Other verses that are central to the Christian faith, but would contradict the religion and morality the state is trying to construct, such as Jesus' command to "Do to others as you would have them do to you," are conveniently overlooked or ignored (New American Bible, Luke 6:31). It is this "scriptural precedent" that allows the state to justify its behavior (Atwood 16). Most of the authorities' usages of scripture, however, are inaccurate interpretations or just plain lies. Once again, Offred's incorrect recollection partway through the novel of a phrase allegedly from "St. Paul in Acts" illustrates this fact (Atwood 117). Christian tradition, of course, holds that St. Luke wrote the Acts of the Apostles. It was certainly not St. Paul, whose epistles predate the Gospel of Luke and the Book of Acts. Offred is unable to recognize this, though, because 
of the education she received at the Rachel and Leah Centers, so she must take the authorities at their word. This demonstrates the state's manipulation and perversion of the actual Christian faith to suit its political needs.

The religious lessons in Gilead are not solely enforced at the Rachel and Leah Re-education Centers. Religious imagery and slogans can be found all throughout the society, constantly reinforcing the importance religion should hold in one's life and its value to the world as a whole. This can especially be seen in the names of places and propaganda. First of all, there is the name of "Gilead" itself, a place mentioned multiple times in the Bible (Genesis 31:25, Numbers 32:1, and Judges 10:4). Within Gilead, though, all the stores the Handmaids visit also have biblical names. For instance, there is "Loaves and Fishes," a reference to Jesus' miraculous feeding of the five thousand; "Milk and Honey," a reference to Canaan, the ancient Israelites' long-awaited promised land; "All Flesh," possibly drawn from Jesus' Bread of Life discourse in the Gospel according to John; and "Lilies," a reference to a line from Jesus' Sermon on the Mount in the Gospel According to Matthew. All these things are undoubtedly meant to be subconscious reminders of the Handmaids' place in Gilead and the lessons they were taught early in their re-education.

Unlike Gilead, the apparatus in The Circle does not use religion to further its agenda. On the contrary, the Circle is intent on superseding religion to become the people's sole source of inner enlightenment. The company's ideological mantra, "Secrets are Lies / Sharing is Caring / Privacy is Theft," almost acts as a religious creed or profession of faith (Eggers 305). It is this mantra that the Circle hopes will inform their customers' code of ethics, not traditional religion. It is through following this code of ethics and using the products that the Circle provides that people will be able to reach enlightenment and become, like God himself, "all-seeing, all-knowing," and all-powerful (Eggers 71). Traditional morals and ethics will no longer be necessary, because the people can police themselves using their technology. Religion itself, therefore, will eventually become obsolete, finding itself replaced by the Circle.

In many ways, Eggers does try to draw connections between the Circle and religion, using traditional religious ideas and imagery to show how the Circle is the fulfillment of everything religion had been trying to do over the millennia. The three founders of the company, for instance, Eamon 
Bailey, Ty Gospodinov, and Tom Stenton, are known throughout the world as the Three Wise Men, a reference to the three foreigners who followed a star to find the newborn Jesus and brought gifts to him (Eggers 19). In a way, these three men can also be seen as a symbol of the Holy Trinity, the God at the head of this particular religion. Each man has a unique role he plays in the company and a specific face he shows to the public. Mae almost deifies them at the beginning of the novel, considering herself unworthy, or at least extremely lucky, to be in their presence (Eggers 27). Religion is also used to emphasize the cult-like nature of the devotion and idealism that believers in the Circle have placed in its rise to power. Eggers introduces an unknown man, a former priesthood candidate who left the seminary to pursue a career in technology, to deliver the message he wants his audience to hear: where religion and faith have failed, the Circle will succeed (398). In his eyes, the company is a fulfillment of everything religion has been striving for, of everything God has wanted humanity to become (Eggers 399). Mae and her friend Francis, though, are so blinded by their faith in the Circle that they laugh in the man's face, showing they have already abandoned God to follow the religion of the Circle (Eggers 399).

The futuristic United States in Fahrenheit 451, meanwhile, has largely set out to destroy anything that remains of religion by burning religious texts and everything they represent. The scriptures that gave rise to the religion of the world have almost entirely been wiped out. According to Montag, the Old and New Testament that he steals "might be the last copy in this part of the world," showing that the Jewish and Christian religions have also disappeared from the world, or at least Montag's part of it (Bradbury 72). This is logical, because religion does not fit well with the materialistic, self-centered society this apparatus has constructed. Faith and spirituality are not necessarily "fun," so there would be no need to hang on to them. Additionally, religion and religious belief lead individuals to ask philosophical questions about their state in life and give them an option for faith, hope, freedom, intellectualism, etc. This, of course, would pose a threat to the state's security, so it has been deemed evil and removed from society.

This does not mean that the state never uses religious ideas or imagery to suit its own needs. They can still be a powerful tool in a world that might have fond memories or affections toward the religious belief of the past. As a result, religious figures like Jesus Christ have been changed from 
loving, liberating teachers to simple members of the family. As Professor Faber tells Montag, "Christ is one of the 'family' now. I often wonder if God recognizes His own son the way we've dressed him up, or is it dressed him down? He's a regular peppermint stick now, all sugar-crystal and saccharine when he isn't making veiled references to certain commercial products that every worshipper absolutely needs" (Bradbury 77). Citizens, especially older ones, may remember Jesus as a person who is supposed to be trusted, a man whose word is honest and believable. Why then would he lie to you while making a commercial pitch on TV? This example shows how the repressive state apparatus deliberately manipulates the religious ISA for its own ends, to reinforce its ideals and consumerist culture. Any religion in this society has been stripped of what it originally meant or intended for its people.

Louis Althusser's theory of repressive and ideological state apparatuses clearly provides an effective way to examine the worlds of dystopian literature and learn why they are so potent at warning their readers of what the world could become. This is an important conversation to have, because reading this type of literature and trying to make connections enables us to recognize these things in our own lives. While many of us will never encounter an evil empire that suppresses its own people just to maintain its power, we will still encounter something similar on a smaller scale. Perhaps it will be a minority group whose civil rights are being infringed upon, or a government whose policies could open the door to misfortune in the future. That is why we read these novels in the first place. They touch on our fears, but they also enable us to open our eyes and recognize these things before they happen to us. 


\section{WORKS CITED}

Althusser, Louis. "Ideology and Ideological State Apparatuses." Marxists Internet Archive, www. marxists.org/reference/archive/althusser/1970/ideology.htm. Accessed 11 February 2018.

Atwood, Margaret. The Handmaid's Tale. Anchor Books, 1998.

Bradbury, Ray. Fahrenheit 451. Simon and Schuster, 2013.

“Dystopia.” New Oxford American Dictionary, 2018, en.oxforddictionaries.com/definition/dystopia. Accessed 27 January 2018.

Eggers, Dave. The Circle. Vintage Books, 2014.

Hurtgen, Joseph. “Archival Domination in Fahrenheit 451.” Journal of Science Fiction, vol. 1, no. 2, May 2016, pp. 36-46.

Koç, Evrim Ersöz. "Subject and State: Ideology, State Apparatuses and Interpellation in Fahrenheit 451." Belgrade English Language and Literature Studies, vol. 7, 2015, pp. 107-133.

Lin, Ethan. "Louis Althusser: 'Ideology and Ideological State Apparatus' \& Overdetermination.” Fu Jen University, english.fju.edu.tw/lctd/asp/theory/theory_works/23/study.htm. Accessed 15 March 2018.

Moradi, Maryam, and Fatemeh Azizmohammadi. "The Study of Ideology in The Handmaid's Tale Based on Althusser's View.” International Letters of Social and Humanistic Sciences, vol. 49, 2015, pp. 75-82.

The Bible. New American Bible, United States Conference of Catholic Bishops, 1970. 